2016-05-03

\title{
Learning to learn in higher education: developing a modus vivendi
}

\author{
Dismore, Harriet
}

http://hdl.handle.net/10026.1/6534

10.1080/02601370.2016.1165746

International Journal of Lifelong Education

Informa UK Limited

All content in PEARL is protected by copyright law. Author manuscripts are made available in accordance with publisher policies. Please cite only the published version using the details provided on the item record or document. In the absence of an open licence (e.g. Creative Commons), permissions for further reuse of content should be sought from the publisher or author. 
Learning to Learn in Higher Education: developing a modus vivendi

Dr Harriet Dismore

Words: 8,383

\section{Corresponding author}

Dr Harriet Dismore

Southampton Education School

University of Southampton

Building 32

Southampton

SO17 1BJ

Email: H.Dismore@soton.ac.uk 


\begin{abstract}
This paper examines the ways in which learning in higher education can influence a person's modus vivendi or way of life. The cases of three individuals following transition to higher education from an apprenticeship in England are presented. Data from individual interviews were analysed according to approaches to reflexivity. In all three cases, the findings show changes to practice in various areas of life and work, which in turn prompted them to revisit their initial concerns. The modus vivendi was influenced by different approaches to reflexivity in addition to new concerns or tensions that arose. Also permeating lived experiences were the role of networks (both personal and at work) and the enjoyment of higher level learning that could act as pivotal enablements or constraints.
\end{abstract}

Keywords: learning, higher education, reflexivity, transition 


\section{Introduction}

Referred to as 'the practice turn' (Schatzki, Knorr-Cetina \& von Savigny, 2001), a shift has been apparent in social theory, away from considering attributes of people as separate but as connected in the practice of events and activities. In education too, various attempts have been made to encapsulate the outcomes of learning from a holistic perspective. For example, Hager and Hodkinson (2009) advocate a need to view learning as becoming, as a changing relational web in a process of ongoing change, inherently part of and shaped by its context, social and embodied. Yet outcomes of learning expressed in this way are not easy to capture. Indeed, the term 'outcome' is commonly used in relation to the more restricted notion of learning outcomes associated with specific units, modules and programmes (e.g. Pampaka \& colleagues, 2012). This paper presents a practice approach to researching ways in which higher education learning influences modus vivendi.

Perhaps the main reason for the relatively slow progress in researching outcomes of learning in a holistic sense is the tendency of learning to be viewed through particular lenses. Many researchers and policymakers continue to regard learning as the acquisition of knowledge (Hager \& Hodkinson, 2009). However, this view of learning assumes that what is learnt is a thing or substance, independent of the learner. Increasingly more emphasis has been given to learning as a social activity by, for example, Lave and Wenger (1991). Rather than asking what kinds of cognitive processes and conceptual structures are involved, they ask what kinds of social engagements provide the proper context for learning to take place. Whilst context is given a great deal of attention, the problem associated with this approach is the neglect of individuals and that 'some versions of situated learning have allowed social to stand in too stark contrast to individual as if they were a natural and essential dualism' (Elkjaer, 2000: 86). The importance of individual transformation is illustrated and emphasised by Mezirow (1991) 
who claims that change occurs via a modification or shifting of meaning perspectives (Illeris, 2014). However, this lens has also been criticised for regarding learning as independent of context and not taking into account relationships or affect (Howie \& Bagnall, 2013).

One way to address relational aspects of learning is to adopt an analytical dualism approach which aims to avoid underplaying or overplaying human agency (Archer, 2003; 2007; 2012). This critical realist perspective (Bhaskar, 1978) starts with the belief that social reality is stratified incorporating both structural and agential strata. The approach not only recognises that agency and structure operate on different timescales, but that human reflexivity can be used to unpick them analytically. In other words, analytical dualism makes it possible to understand how structure and agency emerge, intertwine and redefine one another through the morphogenetic sequence. This sequence also enables us to analyse how structure and agency can be transformed within the same process (double morphogenesis) or simply reproduced (morphostasis).

Archer (2003) identified four modes of reflexivity that influence the way that agency is exercised: autonomous reflexivity when actions are based principally on internal conversations; communicative reflexivity when inner dialogues are shared with others before deciding on a course of action; meta-reflexivity which is concerned with effective action within society; and fractured reflexivity when deliberations can cause such anxiety that purposeful courses of action are prevented. Research drawing on the work of Archer has highlighted that these modes are better described as approaches to be used in any given situation rather than fixed (Dyke et al 2012). Indeed as Archer (2012) and Kahn (2014) argue, learning for a knowledge society favours approaches such as meta-reflexivity that enables one to deal with uncertainty. Arguably, this is increasingly important at a time when the 
phases of adult life have begun to overlap and stretch promoting a fragmented view of learning (Field, 2006).

The ultimate goal of reflexivity is to realise a modus vivendi, 'a set of established practices that constitute a desirable way of life as defined by the subject in the light of his ultimate concerns' (Archer, 2012: 223), both fallible and subject to revision. Exploring modus vivendi can inform not only the future practices of individuals but of policy makers and practitioners. For example, Kahn (2009) in a study investigating entry to higher education and modus vivendi, indicates that interventions designed to widen participation need to take into account different modes of reflexive deliberation. By providing insight into the extent to which agency and structure are transformed via the morphogenetic sequence, analytical dualism is particularly pertinent for analysing outcomes of learning in relation to the modus vivendi.

Changes to circumstances can impact on reflexivity. Archer (2007: 38-41) has argued that reflexivity increases at times of disjuncture between experience and the known, and this produces deliberation on possible courses of action. The focus of this research was following the transition from an apprenticeship to higher education, a progression route that has to date received little attention, despite calls by the UK government to improve it to help widen participation (BIS, 2010). Although there has been an increase in the number of higher education students in the UK, as well as an expansion of vocational higher education qualifications, these changes have not led to widening participation (Ball 2003; Sutton Trust 2005). As Milburn (2012) emphasised in his report on social mobility, UK universities remain less open to people from lower and middle income groups in society than those in countries such as the US or Australia. 
The limited research on the route from an apprenticeship to higher education has mapped provision (Fuller \& Unwin, 2012), examined progression patterns (Smith \& Joslin, 2011) and experiences of transition (Dismore, 2014a, 2014b). To date little research has investigated the role that learning plays in realising a modus vivendi, despite the fact that transitions are recognised as processes which can 'lead to profound change and be an impetus for new learning, or they can be unsettling, difficult and unproductive' (Ecclestone, Biesta \& Hughes, 2010: 2). This paper not only seeks to address this gap but signals the importance of regarding transition as a process of ongoing change rather than entailing an end point (Gale and Parker, 2014), very much in keeping with what Hager and Hodkinson (2009) describe as 'learning as becoming'.

\section{Methodology}

The original project was designed to explore the learning experiences of twenty former apprentices following the transition to higher education. Semi-structured interviews were chosen with a purposefully small sample chosen to collect data, 'to identify inner mechanisms of thought and ultimate matters' (Archer, 2003: 159) and enable detailed investigation into their learning experiences. As an apprenticeship was not a qualification in its own right, the researcher relied on higher education networks to identify former apprentices. The achieved sample of nineteen former apprentices was located in the south of England, working in three broad sectors: computer science, engineering and childcare and the majority worked in engineering (15). The institutions in which they were studying include two further education colleges, one pre-1992 university and four post-1992 universities. The majority of participants were in their 20s (17) and male (15). This pattern broadly reflected the national picture at that time, particularly in relation to the relatively high number of 
apprentices progressing working in engineering, progressing in their 20 s and the greater percentage of those progressing to study at post-1992 institutions (Smith and Joslin, 2011).

In addition to obtaining ethical approval from the University Ethics Committee and assuring all participants that their information would remain anonymous to protect their identity, they were provided with an information sheet and asked to provide their consent. This confirmed their understanding of the process and their right to withdraw at any time without needing to justify their decision. All of the transcripts were returned to each participant for comments and/or amendments before being analysed using the NVivo 10 research software.

For the purpose of this paper, three cases of former apprentices were drawn on to clearly illustrate the learning experiences of individuals. The cases represent the different autonomous, meta-reflexive and communicative modes of reflexive deliberation exercised by those in the achieved sample of nineteen former apprentices. As Table 1 shows, Alan had completed an apprenticeship in engineering operations at a large private aerospace company and was studying for a Bachelor of Arts degree (BA) in business part-time. Ella completed national vocational qualifications (NVQ) levels 2 and 3 before embarking on a Foundation degree in working with children and young people part-time. Mark completed a Higher National Diploma (HNC) before progressing to a Bachelor of Science degree (BSc) in computer science full-time. These cases also articulated clearly how different concerns and tensions emerged and led to changes in practice, making it possible to provide a detailed account of the morphogenetic sequence.

\section{INSERT TABLE 1 HERE}




\section{Findings}

According to Archer (2003), the pursuit of a specific project gives shape to courses of action and ultimately, their modus vivendi. This paper explores the project of transition to higher education according to their reasons for progression, their attitudes towards learning and the perceived outcomes of higher education.

\section{CASE 1: ALAN}

\section{REASONS FOR PROGRESSION}

Alan was 26 years old and had completed an engineering apprenticeship before progressing to a Bachelor in Arts (BA) degree in business. A part-time student, he attended a post-1992 university whilst working at a large private aerospace company. Alan appeared to exercise considerable autonomous reflexivity, illustrated by his strategic planning from the outset. For example, when he first started his apprenticeship his concern was to become a licensed engineer:

I just wanted to fix aeroplanes you know? That was - I was very focused in that sense back then, and that's all I wanted to do and I wasn't really interested in the other things. I think within the first year I was already talking of becoming accredited, you know, I wanted to be a licensed engineer, [for] which you'd need to have, you know, a higher education grade... So I was building the idea of it but not prior to taking up the apprenticeship.

The reference to 'building the idea' suggests a scaffolding approach to learning and learning as building on existing understanding, akin to the learning through personal transformation lens (Illeris, 2014). The idea that he was continually adding to his knowledge and understanding about engineering was confirmed when he explained his reasons for turning his attention to management: 
I think what a lot of people would agree with, you know, a good project manager is somebody who knows a lot about all of it and knows how the crux of it work and so I went, I thought well I need to learn the rest of it, I need to learn the management side, so that's what I started to do. And funnily enough the first graduate post I did was a project management post, and I disproved, or I proved that I didn't like it!

The strategic way he planned his route in order to become a 'good project manager' reflects autonomous reflexivity. Moreover, rather than treating the fact that he did not enjoy managing as a disappointment, rectification followed. He accepted that project management was not necessarily the right path and shifted his focus to business. Later he went on to describe how he took responsibility for meeting with the person who could help facilitate his progression and his decision making:

I wanted to do a business degree and I told her that's what I wanted to do, so she advised that I go away and do my research, find out where it might be best to do that. In turn she'll make enquiries to see if I can join the graduate programme, because that had never been done before. But they felt that the business could best support me whilst I was doing a business degree by being on the graduate programme, because they could align my experiences in the workplace with my learning at university, but also it would offer me some more flexibility in terms of time management.

In other words, the course had to fit in well with his role at work and the company compromised by putting him on the graduate scheme. This is evidence of 'sufficient selfconfidence to marshal their own resources to meet situations...' (Archer, 2007: 194). However, it is also a good example of the morphogenetic cycle; the impact of agency (Alan who is looking to undertake learning) on structural elaboration (to join the graduate programme not normally available to former apprentices). Double morphogenesis was 
detected in the way he talked about the impact of this structural change on his apprehensiveness of being the first person with an apprenticeship background to do the graduate course.

These concerns about the scheme were based on how he perceived university, not uncommon among students from vocational backgrounds (Archer, 2003; Burke, 2012; Fuller \& Unwin, 2012). However, as Archer (2007: 202) states, autonomous reflexivity is characterised by the ability to, 'master the controllable, to minimise the uncontrollable and to live with the unavoidable.' As such, to cope with his concerns about not performing and losing his job, Alan took control of the situation by asking the company to draw up a contract to establish the expectations of him and his employer. Through this interaction, Alan was again reshaping structural relations, not only between himself and his employer but for future employees.

\section{ATTITUDES TOWARDS LEARNING}

An independent learner, Alan enjoyed learning new things and pushing himself to do better: 'I just enjoyed learning new things, I enjoyed learning things that I was interested in, that was why I didn't excel at school.' In other words, he seemed to respond well to what he wanted to learn, a battle described by Archer (2007) as that between a personal project and structural constraints. When asked what he liked about his higher education course, 'Probably the fact that one day I could learn something at university, the next day I could apply, and that's come true a number of times.' In this way, Alan identified himself as a work-related learner with practical application as central to his identity. 
The drive to succeed may in part have been due to his dyslexia and the subsequent 'point to prove' as he put it. He explained how when he first started his apprenticeship he had wanted to 'leave all that behind me'. This determination to carry on without 'special treatment' is another characteristic of autonomous reflexivity. However, this also meant that he had to find alternative methods to learn, for example, using podcasts, iPods, videos. Indeed, he also indicated a desire to do well on his own, rejecting the opportunity to engage in collaborative learning. When explaining what he struggled with in class, he explained, '...you sometimes end up doing extra work and sharing the grade. So it doesn't feel fair'. This preference to work independently is also a trait of autonomous reflexivity, as is developing a trust in his own, rather than others', resources (Archer, 2003). The privileging of those who demonstrate autonomous reflexivity in HE has been commented on by Clegg (2010), especially in the way that it encourages 'self-generational capacities of students' (Barnett, 2003: 148).

\section{OUTCOMES}

Alan's learning experience had been far more positive since doing something he enjoyed and that he could apply. As he explained, he had been achieving a lot of success, so much so that he was enjoying reading.

Over the last three and a half years I've had distinction in everything, apart from one module I think. So, and I put that down to the fact that I'm interested in it, not like I'm a brainiac, [sic] I think it's(!), I just think you know I don't mind sitting at home and reading about it, because do you know what, it's quite interesting. I think that's the big difference ...

In other words, Alan appeared to be developing a modus vivendi which could now involve reading as long as it was of personal interest. 
Other aspects of modus vivendi were also under review. Later in the interview when asked what he wanted to do next, Alan described a, 'switch between what the company wanted and what I wanted' and said that he had taken ownership of his learning which had led to a more positive perspective about his future. This was linked to a general change in the direction that Alan was taking with respect to his goals and career decisions. He described revisiting his initial concerns and adapting his goals to suit his changing circumstances and what he had learned about the management route:

After a couple of years I started to realise just what was actually required at that level. And I don't think it's that I don't feel I can achieve it, it's that I feel that I don't want to! I don't want to be there. Because I've seen it ruin people, ruin their lives, their career might be very successful but quite often what I've seen is that something else suffers.

He mentioned that getting married had also shifted his focus to his life at home. In other words, the goals now related more to other people in his personal network, a trait more often associated with communicative reflexivity. Archer (2003) recognises that as people get older, they can have 'false starts'. Yet the change Alan described is more akin to a carefully monitored decision. Perhaps then it further supports the need to view reflexivity as an approach rather than a fixed mode.

Overall, Alan was a strategic and focused thinker and this was mirrored in the way that he approached learning. His working environment facilitated and encouraged these approaches and thus reinforced his identity as a work-related learner who regarded the practical application of learning as key to sustaining enjoyment and his employment. However, it is interesting to see that at the time of the interview, Alan was undergoing a significant change 
in the way that he considered his identity and consequently, his future role in the company. This is a reminder of the importance of regarding transition as 'becoming' described by Gale and Parker (2014). Their view is that rather than considering specific transitions with an end point, 'transition' (which they also acknowledge then becomes a somewhat redundant term) needs to be viewed as part of a much longer journey. It is not claimed that learning at higher education level was the sole cause of this development as he is clearly experiencing changes in his private life too. However, transition to higher education was shaping his practices, helping him develop a modus vivendi that included learning. One of the ways it did this was by contributing to an increase in confidence, improving his general capability to make decisions not necessarily contingent with the goals of his employer.

\section{CASE 2: ELLA}

\section{REASONS FOR PROGRESSION}

Ella was 31 years old and had completed an apprenticeship in childcare. She had progressed to a further education college to undertake a Foundation degree in childcare part-time whilst working at a private nursery. Ella provided some of the strongest evidence of metareflexivity as demonstrated by her attachment to a set of values, but was also very communicative. Her primary concern was to do her job to 'work with children, be with children...' but she also wanted to learn in order to help children with their 'holistic health', including addressing obesity and speech and language. In this way her value-commitments were not taken for granted but something she 'prioritised, nurtured and promoted' (Archer, 2007: 230). However, this meta-reflexivity was coupled with an autonomous trait, in the sense that she planned to top-up to Bachelor's degree to address wider concerns about the job market. As she explained, 'obviously they're making more cuts and they've just told us even more cuts now, and our job roles will be changing, so we will be re-interviewed for our own 
job we've got now.' This information was based on experiences of other people at work and what they had achieved to sustain employment. For example, when asked why she wanted to do a Foundation degree she added, 'most of the managers within the Children's Centres have the Foundation degree sort of going on, to progress you further, if you want to go into a key area or into management, progress.'

Ella demonstrated low confidence and self-esteem. To counter this, she relied on others to lead the way, such as her manager at work. As someone who had done the same course, her manager would often return to work, 'and say how much she'd learnt and what she's doing there...' Indeed, she said that she simply would not have known about the course unless she had been told about it by her manager who, 'sort of persuaded me into it really'. The existence of Ella's manager as a confidant and supportive colleague was important for her progression to higher education and also to how she applied her learning to the workplace.

\section{ATTIUDES TOWARDS LEARNING}

Ella had not enjoyed her earlier school experience because of difficulties with social situations. As she said, 'It was just a lot of bullying and not a nice school. I just didn't like it, I didn't like school at all. I left with like one friend, it wasn't really the study, it was more the emotional side of it.' In this way, the confidence to speak out at class and feel accepted socially was important to Ella. In addition to suffering from low-confidence in the past, she was also worried that higher education was not necessarily for her. This appeared to be primarily based on how she perceived a 'degree':

...the word 'degree' was oh no, no, no I can't do that, because I haven't done 'A' Levels and I haven't done, you know, haven't gone that route, I've gone work, the work route. 
As Archer (2003) describes, self-criticism is common amongst those who engage in metareflexivity and can often lead to inaction. However, her confidence in class seemed to improve during her time in education. When she compared her own behaviour on an earlier Business and Technology Council (BTEC) course to her apprenticeship and Foundation degree, she perceived differences:

I remember being at school in the BTEC, I was very shy and wouldn't even speak, and on apprenticeship it seemed sort of different, I felt relaxed and confident to speak. And here I can just talk and answer questions and shout out and it's just fine, and it's sort of accepted. Whereas there you thought, I just thought 'oh no I mustn't answer because that's going to be wrong', whereas it doesn't matter if it's wrong now. As this shows, she was developing a modus vivendi which could entail formal learning as long as it took place in a comfortable and supportive environment. As reported by other researchers of widening participation (e.g. Archer, 2003; Burke, 2012; Fuller \& Unwin, 2012), this description is reminiscent of the 'otherness' reported by Burke (2012) and the work of Reay (2001: 337) who highlights the 'difficult balance between investing in a new improved identity and holding onto a cohesive self' among working class higher education applicants. Flam (2010) draws attention to how relations of domination generate emotions that 'silence the voice' of dominated groups. These emotions can be shame, frustration and (suppressed) anger. This is important if as Flam (2010: 191) states, 'the educational system claims its toll, strengthening and cultivating the voice of its best students while silencing the others'. This suggests that learning at higher education had helped Ella find a voice and replace feelings of inferiority with a sense of pride.

\section{OUTCOMES}


Ella's experiences as a Foundation degree student were described in terms of collaborative learning and applying this in the workplace context. Unlike Alan, not only did she find the class supportive, she appeared to be manipulating the learning environment for maximum benefit:

I actually sat in one place for the first few weeks, and then I thought 'no those people are really smart over there', so now I sit in a different place, but they don't know that! (BOTH LAUGH) I sit next to someone who is really intelligent!

Her focus on the social context of learning is more akin to communicative than autonomous reflexivity. Indeed, her desire to communicate may also be responsible for the ways in which she has applied learning in the workplace leading to a change in the working environment. One example of this was helping to change processes and procedures. However as she explained the practices employed had to be implemented in ways that were sensitive to the social dynamics within the workplace. One example was changing the evaluations to demonstrate impact:

we've sort of changed our evaluations, the way we do them, because I've realised we're not showing enough impact, so that's, you know, changed them like that. We now do reflective cycles, because I said how useful it is for me, so now we have time out in the week to do that.

Learning that influences context (or morphogenesis) can be difficult to capture (Hager \& Hodkinson, 2009). Ella was arguably more likely to provide examples of both communicative and meta-reflexivity because of working with children, a social and socially responsible role that relies on learning through participation. In order to succeed in this work, she had to be able to demonstrate these traits, drawing on the reflective skills that the course entailed. This 
was particularly evident in the way that Ella responded to an Ofsted inspection. Drawing on this particular experience, Ella was able to describe how she directly influenced an inspection: ...she [the Ofsted Inspector] came back a little bit later and asked me about festivals, and someone said 'oh yeah we've got a board'. Then she left, and I thought 'no, that's not good enough, not good enough', so I went to her and I said 'you need to come and observe my group this afternoon'. I never would have done that before because I know there's, I'm doing all about festivals, I'm doing all about Eid, and I thought 'no that's not good enough', whereas I never would have done that before. And all the diversity, I knew I was going to have teenage mums in there, and I have a foster mum! And I needed her to come and see what we were doing.

Communicating her new knowledge to others extended to the parents. As she made clear, the more she learned at college, the more she was able to explain and provide possible reasons for children's behaviour:

I [am] sort of more confident to tell them and give them advice, whereas before I'd think 'I don't know'. And now I, if they ask me something and I think 'I don't know but I'm going to go and find out', and it might be at college, it might be here, and then I'll tell them the reason behind it, or you know the theory of why.

These examples illustrate how learning led to structural elaboration via the morphogenetic sequence (Archer, 1995). The interactions of Ella with higher education learning had resulted in consequences that themselves led to changes in the way that the workplace operated (and in the case of Ofsted, how it was perceived). Understanding this not only transformed Ella's perceptions of herself (increasing her confidence) but it added to the practices that she would employ as part of her modus vivendi. 
Ella's personal transformation was emphasised when she talked about how she wished to proceed. As she explained, 'I want to learn, I'm not there to muck about or you know...I wish I'd listened, I wish I'd done better at school and things!' As this shows, the main outcome for Ella was that she was enjoying learning to learn. In her words, 'I can't wait to come here on a Friday and I can't wait to learn what we're going to learn.' This epitomises the vision suggested by Säljö (2003: 317), who wishes to focus on organising learning so that, 'students appreciate being in a position of acting as learners'.

However, coupled with this was a growing concern between learning for the wider benefits it brought and what she needed to do for her career given the wider economic and employment issues. As she explained,

because I know that I'm enjoying it so much and I don't really want it to stop, I want to carry on. And then obviously I need to look into which way I'm going to go, what else I need to do after, because obviously if, if I do want to be a speech and language therapist it's going to be three years' training, so that might not be the route that, this might be a quicker route to go down.

This clearly demonstrates the tension between meta and autonomous reflexivity as Ella made the choice between effective action in society and her own career aspirations. Archer (2007) too discusses the increasing reliance on meta-reflexivity among young people who confront open opportunities, in a late modernity characterised by 'contextual discontinuity'. In other words, like Alan, she was prompted to return to the reasons for pursuing higher education in the first place. Her modus vivendi was being revisited around a desire to learn. 


\section{CASE 3: MARK}

\section{REASONS FOR PROGRESSION}

Mark was 23 years old and had completed an apprenticeship in business and administration whilst working at a small information and technology company. He then decided to leave his job in order to pursue a degree full time. Mark had completed his BSc in Computer Science and, together with the Programme Director, had applied for funding to continue working on a project over the summer.

The exact reasons for leaving school to begin an apprenticeship were primarily because Mark wished to earn money. As he explained, 'at first, I just wanted to get on and do some work, to earn some money and progress in that way, I didn't want to, I didn't want to continue with the education side so much.' In a similar way to other apprentices (Brockmann, 2010), Mark had been disenchanted with school itself but attracted to what he enjoyed: 'I'd always liked computers, always, but I wasn't sure that I was, I really wasn't sure what I was going to do when I left school. I knew that I didn't want to be there anymore but I didn't know where I wanted to be.' This uncertainty is common among young people and is an example of what Archer (2012: 109) refers to as 'fluid concerns'. It is difficult for them to match concerns with employment because they know too little about themselves and about swiftly changing opportunities.

Like Ella, Mark had been encouraged by his manager to go on to higher education. However, the decision to progress was also informed by a perceived need to get qualifications for employment.

When I left school (laughs) I was maybe a bit cocky and thought 'oh I don't need to do this, I'll just go out and get a job'! But then once I started looking around for jobs 
that I could earn a liveable amount off, they were all $2: 1 \mathrm{~s}$, minimum $2: 1$, very minimum 2:2, Masters, so I thought 'no I need to go and do this, I need to get that qualification'...

However, there existed a tension between this perceived need and another concern: I felt quite nervous, if only because I was going to not have my job and my familiar surroundings and my steady stream of money, so I'd shoved loads of money away. I think my mum was quite happy, she was quite, I don't think she'd say it but she wasn't that happy when I left school, but she said, it's your decision, do what you want, but I think she was quite happy when I went back.

Autonomous reflexivity is characterised by contextual discontinuity, which as his words suggest, were not something Mark found easy to overcome. His concerns focused on how he would balance the studying with his work commitments if he remained employed and discovered that he would have to give up his job to pursue the degree full time. This appeared to increase his anxiety, as he recognised what he would have to give up in return for doing the course. The tensions of seeking to obtain higher-level qualifications and the demands of employers have been rehearsed elsewhere (e.g. Coffield, 1999). Interestingly however, the decision was also considered in light of his mother's reaction. This weighing up of considerations is at the heart of reflexivity. It shows the important and often ignored role of social networks in making such decisions (Fuller et al. 2012). It also highlights the pressure on learners not to 'stay put' and that to do so suggests personal failure (Clegg, 2010). Indeed, this message is also central to the widening participation discourse targeted at groups such as former apprentices in higher education (Burke, 2012).

\section{ATTITUDES TOWARDS LEARNING}


Mark described how during his $\mathrm{HNC}$ he discovered that his main interest was in computer science. Mark identified himself as a 'hands on' learner and talked about his persistence when trying to get things to work. The description of undertaking this lone exercise is also a feature of autonomous reflexivity, preferring individualist to group activities:

...with computing it's a bit more hands on, so you can get away with being not so good at that if you're very practical and I think I made up with lack of those skills with practical ... Instead of sitting there and reading a book on programming, I'd sit there, probably for twice as long, and muck about with it until it worked sort of thing.

Despite his successful completion of an undergraduate degree, he continued to talk in deficit terms about his skills, one of which was reading. Whereas Alan found interesting things to read, Mark concentrated on the practical skills. For Mark, the fact that higher education relied on the ability to read extensively was a barrier he felt he had to overcome. Yet, he was driven increasingly by the determination to know: 'Before I started doing anything in higher education I thought I knew quite a lot about computers, but once I started I realised that I knew nothing.' Archer (2003) similarly noted that taking responsibility for perceived shortcomings and self-monitoring is important for autonomous reflexivity. In this way, Mark's modus vivendi was undergoing significant development in light of his new learning. Where his departs from the learning of Alan and Ella is the perception of how little he knew and how much more he had to learn, prompting a shift in terms of how he viewed himself as a learner. As a full time student, his experiences were around transformational learning, leading to individual change and less to do with morphogenetic processes whereby contexts are changed.

\section{OUTCOMES}


This learning transformation was demonstrated in the way Mark was able to articulate not only how he felt about learning in the present but how he had changed as a learner over the years. For example, he was able to reflect on when he became a more active learner:

It was after the HNC, it was really once I came here that ... Whereas before I'd been a bit passive in the learning, I just, I'd go to the classes, I listened to what they had to say but I was very passive about it all. After coming here and I don't know, maybe it was the paying $£ 3,000$ (laughs), suddenly I got a lot more active.

This also explains the central role that learning played in his life more generally. When, at the end of the interview, Mark was asked what he enjoyed about learning, he explained that it was

Ooh I tell you, the bit I like is when you learn one thing and you learn something else that you think is completely different and then you find out that you can apply it or generalise it or some way and they sort of tie in to one another.

This type of learning is identified by Illeris (2009) as accommodative learning, whereby new elements not immediately related are applied and perhaps even transformed. This seems to demonstrate an awareness of his field and his advancing knowledge through actively making links and connections. Unlike Ella who relied on communicating her new knowledge in a social context, Mark was immersed in a world that consisted of him mainly alone with technology, causing him to measure any success according to his own learning transformation. In fact, his references to the affective domain of learning (loving and liking) were made regularly during the interview. Although few studies have been conducted examining specifically the influence of learning on emotions (Goetz et al. 2006), this is clearly an important response which is encouraging him to continue with his studies. Overall, there was a real sense during the interview that Mark had begun a new journey and was very aware of his process of 'becoming'. 


\section{DISCUSSION}

This paper examined the relationship between higher education learning and a person's modus vivendi or way of life, by drawing on the cases of three individuals following transition to higher education from an apprenticeship. The cases represent the different modes of reflexive deliberation expressed by those in the achieved sample of nineteen former apprentices from which this was drawn, enabling a detailed investigation of the data on their learning journeys. The focus on particular cases was also important considering the challenges of researching learning:

Learning does not have a clear physical or reified identity in the world. Rather, learning is a concept constructed and developed by people to label and thus start to explain some complex processes that are important in our lives. (Hodkinson \& Macleod, 2010:174)

The study of reflexivity offers a sophisticated approach to understanding learning (Dyke, 2013; Kahn et al. 2012), showing how different approaches to reflexivity guide how people navigate the constraints and enablements. However, this on its own cannot explain how changes are made in relation to context and practices. As Archer (2007: 87) states, 'the goal of defining and ordering our concerns, through what is effectively a life-long internal conversation, is to arrive at a satisfying and sustainable modus vivendi'. This study reveals some ways in which higher education learning can contribute to establishing a way of life and the complexities involved.

Clegg (2010) has stated that higher education valorises autonomous reflexivity in particular and to an extent this paper supports that claim. All of the participants needed to demonstrate 
some autonomous reflexivity to pursue higher education, especially from an apprenticeship pathway, which so few follow (Burke, 2012). This autonomous reflexivity took the form of strategic planning and internal conversations. For all of the participants this seemed inextricably linked to beliefs about the importance of obtaining qualifications for employment.

The findings also suggest that modes of learning and subject areas may suit different approaches to reflexivity for learning. For example, Ella was engaging in a course which encouraged meta-reflexivity and assessed reflective skills. As such, she was able to articulate the impact and implications of her learning in practice. In contrast, Mark was engaged much more in transformative learning that relied more on independent learning and autonomous reflexivity. This in turn was connected to the mode of learning. Part time students could demonstrate morphogenetic processes more easily due to opportunities to apply learning to the workplace and change workplace practices.

In all cases, participants were revisiting their original concerns and modus vivendi in light of their new learning. For example, Alan had learned that he wanted to take ownership over his learning, the aims of which were not necessarily perceived to be the same as his employer. Mark believed that he actually knew less than he had thought and to rectify this, learning had become the main focus of his life. Ella was reflecting regularly on her impact in practice and drawing on it to inform her future choices. In this way the study shows the role that reflexivity plays in the positioning of individuals as they generate distinctive trajectories but highlights the fact that no constant conjuncture between the personal and social can be expected (Archer, 2007). 
These re-evaluations tended to be around reconciling aspects of life and interests with employment aims. For example, Ella was mindful of the conflict between what she needed to do for her longer term work goals and her enjoyment of learning. Alan was concerned about the impact of his work on his personal and home life. This can be attributed in part to the taken for granted relationship between educational attainment and credentials and socioeconomic attainment (Bills, 2003). Indeed, as Kahn and colleagues (2012) note, the connection between higher education and modus vivendi is particularly strong given the increasing focus on the knowledge economy and society.

Networks and enjoyment of learning were two themes that warrant further investigation. Research investigating widening participation in higher education has shown the value of collecting data from networks for understanding the personal and collective aspects of decision making (Fuller et al. 2011). Indeed, reporting on the same study the researchers explained that 'we gain different insights into individuals from the accounts of their network of friends and family' (Dyke et al. 2012: 25). The findings of this paper also suggest that for sustaining interest and communicating learning to others, enjoying and 'loving' learning was paramount. Indeed, UK educational policy texts repeatedly highlight the notion of enjoyment (Lumby, 2011). For example, in the White Paper Students at the Heart of the System it is announced that,

Education should not stop when a person leaves school. The opportunities and enjoyment it offers should be available to people throughout their lives in different forms: full-time and part-time; academic and vocational, whatever will help them achieve their goals at that stage of their life. (BIS, 2011)

This frames enjoyment as a right rather than a tool to raise attainment. Yet other policies make this aim increasingly difficult, such as the introduction of the equivalent and lower 
qualification fee (ELQ) that discourages people from studying at the same or lower level than the qualification they already hold. There also remains little research about the enjoyment of learning elsewhere despite claims that an absence of enjoyment is one of the reasons people fail to reach their potential (Goetz et al. 2006).

Future research needs to address the principles of lifelong and lifewide learning in relation to reflexivity and how it is used to align personal identity with social identity via the modus vivendi or way of life. As Reay (2001) argues, it often takes great personal courage and determination to pursue higher education from a vocational route. Indeed, owing to a number of factors such as economic recession and an aging population, lifelong learning has not only become a macro theme central to EU policy, there has been an increasing emphasis on the individual at the centre of the educational process (Volles, 2014). However the numbers of mature part time learners has slowly declined over the last five years, raising concerns about the prospects for upskilling of adults for economic development (Universities UK, 2013). Whilst the transition from an apprenticeship to higher education is just one time of disjuncture when reflexivity can increase, understanding how people navigate this progression can help us support individuals in the future and ensure that higher education leads to sustainable practices for lifelong learning.

\section{Acknowledgements}

This research was supported by the Society for Research into Higher Education (SRHE). I am also grateful to all of the participants who gave their time and consent to be interviewed. 


\section{References}

Archer, M. (2012) The Reflexive Imperative in Late Modernity. Cambridge: Cambridge University Press.

Archer, M. (Ed.) (2010) Conversations about Reflexivity. Abingdon: Routledge.

Archer, M. (2007) Making Our Way Through the World: human reflexivity and social mobility. Cambridge: Cambridge University Press.

Archer, M. (2003) Structure, Agency and the Internal Conversation. Cambridge: Cambridge University Press.

Archer, M. (1995) Realist Social Theory: the morphogenetic approach. Cambridge: Cambridge University Press.

Ball, S. (2003) Class Strategies and the Education Market. London: Routledge.

Barnett, R. (2003) Beyond All Reason: Living with Ideology in the University. Buckingham: SRHE and Open University Press.

Bhaskar, R. (1978) A Realist Theory of Science. London: Verso.

Bills, D. (2003) Credentials, signals, screens and jobs: explaining the relationship between schooling and job assignment. Review of Educational Research, 74 (4), pp. 441-469.

Brockmann, M. (2010) Identity and apprenticeship: the case of English motor vehicle maintenance apprentices. Journal of Vocational Education \& Training 62 (1): 63-73.

Burke, P.-J. (2012) The Right to Higher Education: Beyond Widening Participation. London: Routledge.

Business, Innovation and Skills (BIS) (2011) Students at the Heart of the System https://www.gov.uk/government/uploads/system/uploads/attachment_data/file/32409/ 11- 944-higher-education-students-at-heart-of-system.pdf. Accessed 28th August 2013. 
Business, Innovation and Skills (BIS) (2010) Skills for Sustainable Growth http://www.bis.gov.uk/assets/BISCore/further-education-skills/docs/S/10-1274-skillsfor-sustainable-growth-strategy.pdf. Accessed 29th August 2013.

Clegg, S. (2010) Time future - the dominant discourse of higher education, Time \& Society 19 (3), 345-364.

Coffield, F. (1999) Breaking the consensus: lifelong learning as social control, British Educational Research Journal, 25 (4), 479-499.

David, P. and Foray, D. (2002) Economic fundamentals of the knowledge society, International Social Science Journal, 171,149-167.

Dismore, H. (2014a) Experiencing the transition from an apprenticeship to higher education. Journal of Education and Work, 27 (6), 585-607.

Dismore, H. (2014b) From apprenticeship to higher education: navigating the credential landscape. Journal of Vocational Education and Training, 66 (3), 386-405.

Donati, P. (2010) Reflexivity after modernity: from the viewpoint of relational sociology. In M. Archer (Ed.) Conversations about Reflexivity (pp. 144-165). London: Routledge. Drucker, P. F. (1993) The Post-capitalist Society. New York: HarperCollins.

Dyke, M. (2013) Reconceptualising learning as a form of relational reflexivity. British Journal of Sociology of Education. DOI: 10.1080/01425692.2013.843445

Dyke, M., Johnston, B. and Fuller, A. (2012) Approaches to reflexivity: navigating educational and career pathways. British Journal of Sociology of Education, 33 (6), $831-848$

Ecclestone, K., Biesta, G. and Hughes, M. (2010) Transitions in the lifecourse: the role of identity, agency and structure. In K. Ecclestone, G. Biesta and M. Hughes (Eds.) Transitions and Learning through the Lifecourse. London: Routledge. 
Elkjaer, B. (2000) The continuity of action and thinking in learning: Re-visiting John Dewey. Outlines, 2, 85-101.

Field, J. (2006) (2 ${ }^{\text {nd }}$ Ed.) Lifelong Learning and the New Educational Order. Stoke on Trent: Trentham Books.

Flam, H. (2010) Emotion, and the silenced and short-circuited self. In M. Archer (Ed.) Conversations about Reflexivity (pp. 187-206). London: Routledge.

Fuller, A. and Unwin, L. (2012). Banging on the Door of the University: the complexities of progression from apprenticeship and other vocational programmes in England. Monograph No. 14. Cardiff: SKOPE.

Fuller, A., Heath, S. and Johnston, B. (2011) Rethinking Widening Participation in Higher Education. The role of social networks. London: Routledge.

Gale, T. and Parker, S. (2014) Navigating change: a typology of student transition in higher education. Studies in Higher Education, 39 (5), 734-753.

Goetz, T., Nathan C., Hall, B., Anne, C., Frenzel, A. and Pekrun, R. (2006) A hierarchical conceptualization of enjoyment in students, Learning and Instruction, 16, 323-338.

Hager, P., and Hodkinson, P. (2009) Moving Beyond the Transfer of Learning. British Educational Research Journal 35 (4): 619-638.

Hodkinson, P. and Macleod, F. (2010) Contrasting concepts of learning and contrasting research methodologies: affinities and bias, British Educational Research Journal, $36(2), 173-189$.

Howie, P. and Bagnall, R. (2013) A beautiful metaphor: transformative learning theory, International Journal of Lifelong Education, 32 (6), 816-836.

Illeris, K. (2009) A comprehensive understanding of human learning. In K. Illeris (Ed.) Contemporary Theories of Learning (pp.7-21). London: Routledge.

Illeris, K. (2014) Transformative Learning and Identity. London: Routledge. 
Kahn, P. (2014) Theorising Student Engagement in Higher Education. British Educational Research Journal, 40 (6), 1005-1018.

Kahn, P. (2009) On establishing a modus vivendi: the exercise of agency in decisions to participate or not participate in higher education, London Review of Education, 7 (3), 261-270.

Kahn, P., Qualter, A. and Young, R. (2012) Structure and agency in learning: a critical realist theory of the development of capacity to reflect on academic practice, Higher Education Research \& Development, 31 (6), 859-871.

Lave, J. and Wenger, E. (1991) Situated Learning: legitimate peripheral participation. Cambridge: Cambridge University Press.

Lumby, J. (2011) Enjoyment and learning: policy and secondary school learners' experience in England, British Educational Research Journal, 37 (2), 247-264.

Mezirow, J. (1991) Transformative Dimensions of Adult Learning. San Fransisco, CA: Jossey-Bass.

Milburn, A. (2012) University Challenge: How Higher Education Can Advance Social Mobility. a Progress Report by the Independent Reviewer on Social Mobility and Child Poverty. London: Cabinet Office.

Pampaka, M., Williams, J. and Hutcheson, G. (2012) Measuring students' transition into university and its association with learning outcomes, British Educational Research Journal, 38(6), 1041-1071.

Reay, D. (2001) Finding or losing yourself? Working-class relationships to education, Journal of Education Policy, 16 (4), 333-346.

Saljö , R. (2003) From transfer to boundary-crossing, in: T. Tuomi-Gröhn \& Y. Engeström (Eds) Between school and work: new perspectives on transfer and boundarycrossing (pp. 311-321). Amsterdam: Elsevier Science. 
Schatzki, T., Knorr Cetina, K. and von Savigny, E. (2001) The Practice Turn in Contemporary Theory. London: Routledge.

Smith, S. and Joslin, H. (2011) Apprentice Progression Tracking Research Project Report. Longitudinal tracking of advanced level apprentice cohorts progressing into higher education 2005-06 to 2009-10. Centre for Work-Based Learning: University of Greenwich.

Sutton Trust. (2005) State School Admissions to Our Leading Universities an Update to "The Missing 3000”. London: Sutton Trust.

Universities UK (2013) The Power of Part-time: Review of part-time and mature higher education. Universities UK: London.

Volles, N. (2014) Lifelong learning in the EU: changing conceptualisations, actors and policies, Studies in Higher Education, DOI:10.1080/03075079.2014.927852. 